\title{
Study Overall Status Code
}

National Cancer Institute

\section{Source}

National Cancer Institute. Study Overall Status Code. NCI Thesaurus. Code C94097.

A coded value specifying the phase in the lifecycle of the study as a whole. 